\title{
Corrigendum: Evaluation of the SARS-CoV-2 Inactivation Efficacy Associated With Buffers From Three Kits Used on High-Throughput RNA Extraction Platforms
}

Ruth E. Thom, Lin S. Eastaugh, Lyn M. O'Brien, David O. Ulaeto, James S. Findlay, Sophie J. Smither, Amanda L. Phelps, Helen L. Stapleton, Karleigh A. Hamblin and Simon A. Weller*

CBR Division, Dstl Porton Down, Salisbury, United Kingdom

OPEN ACCESS

Edited and reviewed by: Max Maurin,

Université Grenoble Alpes, France

*Correspondence: Simon A. Weller sweller@dstl.gov.uk

Specialty section:

This article was submitted to

Clinical Microbiology,

a section of the journal

Frontiers in Cellular and

Infection Microbiology

Received: 11 November 2021 Accepted: 23 November 2021 Published: 08 December 2021

Citation:

Thom RE, Eastaugh LS, O'Brien LM, Ulaeto DO, Findlay JS, Smither SJ,

Phelps AL, Stapleton HL, Hamblin KA and Weller SA (2021) Corrigendum:

Evaluation of the SARS-CoV-2

Inactivation Efficacy Associated With Buffers From Three Kits Used on HighThroughput RNA Extraction Platforms. Front. Cell. Infect. Microbiol. 11:813442. doi: 10.3389/fcimb.2021.813442
Keywords: SARS-CoV-2, high throughput, PCR, biosafety, laboratory-acquired infection, clinical diagnosis

\section{A Corrigendum on}

Evaluation of the SARS-CoV-2 Inactivation Efficacy Associated With Buffers From Three Kits Used on High-Throughput RNA Extraction Platforms

By Thom RE, Eastaugh LS, O'Brien LM, Ulaeto DO, Findlay JS, Smither SJ, Phelps AL, Stapleton HL, Hamblin KA and Weller SA (2021). Front. Cell. Infect. Microbiol. 11:716436. doi: 10.3389/fcimb.2021.716436

In the original article, there was a mistake in Table 1: Protocols tested for assessing inactivation using lysis buffers as published. During the publication process the components for each of the three kits tested in this study (as stated in the 'Reagents' and 'Active virucidal components' columns), were unclearly formatted. The corrected Table 1: Protocols tested for assessing inactivation using lysis buffers appears below.

The authors apologize for this error and state that this does not change the scientific conclusions of the article in any way. The original article has been updated.

Publisher's Note: All claims expressed in this article are solely those of the authors and do not necessarily represent those of their affiliated organizations, or those of the publisher, the editors and the reviewers. Any product that may be evaluated in this article, or claim that may be made by its manufacturer, is not guaranteed or endorsed by the publisher.

Copyright (C) 2021 Thom, Eastaugh, O'Brien, Ulaeto, Findlay, Smither, Phelps, Stapleton, Hamblin and Weller. This is an openaccess article distributed under the terms of the Creative Commons Attribution License (CC BY). The use, distribution or reproduction in other forums is permitted, provided the original author(s) and the copyright owner(s) are credited and that the original publication in this journal is cited, in accordance with accepted academic practice. No use, distribution or reproduction is permitted which does not comply with these terms. 
TABLE 1 | Protocols tested for assessing inactivation using lysis buffers.

Manufacturer, RNA extraction kit, Platform

Reagents (volume/sample)

Active virucidal components*

ACL buffer $(190 \mu l)$

ATL buffer $(100 \mu \mathrm{l})$

Proteinase K $(20 \mu)$

Carrier RNA $(5 \mu \mathrm{l})$ MS2 (10 $\mu \mathrm{l})$

(Cat \#: 57731),

Qiagen Qiacube HT.

(Referred to here as Qiagen protocol)
Lysis binding buffer (350 $\mu$ l)

Isopropanol (300 $\mu$ l)

Carrier RNA $(2 \mu \mathrm{l})$

Water $(100 \mu \mathrm{l})$ MS2 (10 $\mu \mathrm{l})$
Reagent: Sample ratio

GITC $30-<50 \%$

$1-<3 \%$ SDS
1.6: 1

ThermoFisher,

MagMax Pathogen RNA/DNA kit

(Cat \#: 4462359),

Kingfisher Flex.

(Referred to here as MagMax Protocol 1)

Lysis binding buffer $(265 \mu \mathrm{l})$

Proteinase $\mathrm{K}(5 \mu \mathrm{l})$

†Water (Magnetic beads) $(10 \mu \mathrm{l})$

ThermoFisher,

MagMax viral/pathogen nucleic acid isolation kit

(Cat \#: A48310),

Kingfisher Flex.

(Referred to here as MagMax Protocol 2)

$$
\text { MS2 }(10 \mu l)
$$

*As identified directly from components, manufacturer information, or inferred from the associated MSDS.

${ }^{t}$ Water was used to replace the magnetic beads as the washing steps described below would not remove the beads and the beads interfered the read-out of the TCID- 50 assay.

GITC, Guanidinium thiocyanate; SDS, Sodium dodecyl sulphate.

GITC 55-80\%

$<0.001 \%$ Acrylamide

Zwittergent

GITC 55-80\% <0.001\% Acrylamide

3.8: 1

Zwittergent

100\% 2-propanol 